\title{
Brown carbon's emission factors and optical characteristics in household biomass burning: developing a novel algorithm for estimating the contribution of brown carbon
}

\author{
Jianzhong Sun ${ }^{1,2} \star$, Yuzhe Zhang ${ }^{1} \star$, Guorui Zhi ${ }^{1}$, Regina Hitzenberger ${ }^{3}$, Wenjing Jin ${ }^{1}$, Yingjun Chen ${ }^{4}$, Lei Wang ${ }^{1}$, \\ Chongguo Tian ${ }^{5}$, Zhengying Li ${ }^{1}$, Rong Chen ${ }^{6}$, Wen Xiao ${ }^{7}$, Yuan Cheng ${ }^{8}$, Wei Yang ${ }^{2}$, Liying Yao $^{2}$, Yang Cao $^{2}$, \\ Duo Huang ${ }^{2}$, Yueyuan Qiu ${ }^{2}$, Jiali Xu ${ }^{2}$, Xiaofei $\mathrm{Xia}^{2}$, Xin Yang ${ }^{2}$, Xi Zhang ${ }^{2}$, Zheng Zong ${ }^{5}$, Yuchun Song ${ }^{9}$, and \\ Changdong $\mathrm{Wu}^{9}$ \\ ${ }^{1}$ State Key Laboratory of Environmental Criteria and Risk Assessment, Chinese Research Academy of Environmental \\ Sciences, Beijing 100012, China \\ ${ }^{2}$ School of Physical Education, Shangrao Normal University, Shangrao 334001, China \\ ${ }^{3}$ University of Vienna, Faculty of Physics, Boltzmanngasse 5, 1090 Vienna, Austria \\ ${ }^{4}$ Shanghai Key Laboratory of Atmospheric Particle Pollution and Prevention (LAP3), Department of Environmental Science \\ and Engineering, Fudan University, Shanghai 200438, China \\ ${ }^{5}$ Key Laboratory of Coastal Environmental Processes and Ecological Remediation, Yantai Institute of Coastal Zone Research, \\ Chinese Academy of Sciences, Yantai 264003, China \\ ${ }^{6}$ College of Physical and Health Education, East China Jiaotong University, Nanchang 330006, China \\ ${ }^{7}$ School of Physical Education, Jiangxi Science \& Technology Normal University, Nanchang 330006, China \\ ${ }^{8}$ State Key Laboratory of Urban Water Resource and Environment, School of Environment, Harbin Institute of Technology, \\ Harbin 150001, China \\ ${ }^{9}$ Jiangxi Sports Hospital, Nanchang 330006, China \\ ^These authors contributed equally to this work.
}

Correspondence: Guorui Zhi (zhigr@ craes.org.cn) and Yingjun Chen (yjchenfd@fudan.edu.cn)

Received: 4 June 2020 - Discussion started: 23 July 2020

Revised: 20 December 2020 - Accepted: 22 December 2020 - Published: 17 February 2021

\begin{abstract}
Recent studies have highlighted the importance of brown carbon $(\mathrm{BrC})$ in various fields, particularly relating to climate change. The incomplete combustion of biomass in open and contained burning conditions is believed to be a significant contributor to primary $\mathrm{BrC}$ emissions. So far, few studies have reported the emission factors of $\mathrm{BrC}$ from biomass burning, and few studies have specifically addressed which form of light-absorbing carbon, such as black carbon (BC) or BrC, plays a leading role in the total solar light absorption by biomass burning. In this study, the optical integrating sphere (IS) approach was used, with carbon black and humic acid sodium salt as reference materials for $\mathrm{BC}$ and $\mathrm{BrC}$, respectively, to distinguish $\mathrm{BrC}$ from $\mathrm{BC}$ on filter samples. A total of 11 widely used biomass types in China were burned in a typical stove to simulate the real
\end{abstract}

household combustion process. (i) Large differences existed in the emission factors of $\mathrm{BrC}\left(\mathrm{EF}_{\mathrm{BrC}}\right)$ among the tested biomass fuels, with a geometric mean $\mathrm{EF}_{\mathrm{BrC}}$ of $0.71 \mathrm{~g} \mathrm{~kg}^{-1}$ (0.24-2.09). Both the plant type (herbaceous or ligneous) and burning style (raw or briquetted biomass) might influence the value of $\mathrm{EF}_{\mathrm{BrC}}$. The observed reduction in the emissions of light-absorbing carbon (LAC) confirmed an additional benefit of biomass briquetting in climate change mitigation. (ii) The calculated annual $\mathrm{BrC}$ emissions from China's household biomass burning amounted to $712 \mathrm{Gg}$, higher than the contribution from China's household coal combustion $(592 \mathrm{Gg})$. (iii) The average absorption Ångström exponent (AAE) was $(2.46 \pm 0.53)$, much higher than that of coal-chunk combustion smoke (AAE $=1.30 \pm 0.32$ ). (iv) For biomass smoke, the contribution of absorption by $\mathrm{BrC}$ to the 
total absorption by $\mathrm{BC}+\mathrm{BrC}$ across the strongest solar spectral range of $350-850 \mathrm{~nm}\left(F_{\mathrm{BrC}}\right)$ was $50.8 \%$. This is nearly twice that for $\mathrm{BrC}$ in smoke from household coal combustion $(26.5 \%)$. (v) Based on this study, a novel algorithm was developed for estimating the $F_{\mathrm{BrC}}$ for perhaps any combustion source $\left(F_{\mathrm{BrC}}=0.5519 \ln \mathrm{AAE}+0.0067, R^{2}=0.999\right)$; the $F_{\mathrm{BrC}}$ value for all global biomass burning (open + contained) $\left(F_{\mathrm{BrC}-\text { entire }}\right)$ was $64.5 \%(58.5 \%-69.9 \%)$. This corroborates the dominant role of $\mathrm{BrC}$ in total biomass burning absorption. Therefore, the inclusion of $\mathrm{BrC}$ is not optional but indispensable when considering the climate energy budget, particularly for biomass burning emissions (contained and open).

\section{Introduction}

Brown carbon $(\mathrm{BrC})$ refers to the fraction of organic carbon (OC) that is light-absorbing, with a pronounced wavelength dependence of absorption (Kirchstetter et al., 2004; Bosch et al., 2014; Chakrabarty et al., 2014; Mo et al., 2017; Jiang et al., 2018; Sun et al., 2018). Recent studies have highlighted the importance of $\mathrm{BrC}$ in not only atmospheric chemistry, air quality, and human health, but also for climate change (Chakrabarty et al., 2010; Huang et al., 2018; Yan et al., 2018; Han et al., 2020). Light absorption by $\mathrm{BrC}$ is more emphasized towards short wavelengths (IPCC, 2014; Pokhrel et al., 2017; Li et al., 2018; Xie et al., 2018; Ferrero et al., 2020). By calculating the radiative forcing (RF) of $\mathrm{BrC}$ at the surface and at the top of the atmosphere, Park et al. (2010) found that more than $15 \%$ of the total RF caused by light-absorbing carbon (LAC, including $\mathrm{BrC}$ and BC) could be attributed to BrC. Yao et al. (2017) demonstrated that a positive direct radiative effect (DRE) of absorption $\left(+0.21 \mathrm{~W} \mathrm{~m}^{-2}\right)$ was caused by BrC-containing organic aerosols from the burning of crop residues in East China during the summer harvest season. This is indicative of the negative effects on not only air quality, but also on climate. Pokhrel et al. (2017) found that absorption by $\mathrm{BrC}$ at shorter visible wavelengths was equal to or greater than that by $\mathrm{BC}$.

The incomplete smoldering combustion of biomass in open environments or contained stoves is a major contributor to primary BrC emissions (Lukács et al., 2007; Chakrabarty et al., 2010; Hecobian et al., 2010; Chakrabarty et al., 2013). High gas and particle emissions have often been observed during these combustion processes (Kirchstetter et al., 2004; Chen and Bond, 2010; Bosch et al., 2014; Budisulistiorini et al., 2017). Ground-based observations and model simulations have revealed that in some regions with high biomass consumption intensities, such as South America, South Asia, Africa, Russia, China, and India, high column concentrations of $\mathrm{BrC}\left(10-35 \mathrm{mg} \mathrm{m}^{-2}\right)$ are found in the atmosphere (Arola et al., 2011; Feng et al., 2013; Huang et al., 2018). In these regions, the climatic effects of $\mathrm{BrC}$ are expected to be stronger than in other regions.
In China, biomass burning contributes a substantial quantity of carbonaceous particles, along with many other air pollutants. The available emission inventories show that approximately $20 \%$ of primary fine particulate matter $\left(\mathrm{PM}_{2.5}\right)$ originates from biomass burning (open and contained) (Yao, 2016). Zong et al. (2017) used the positive matrix factorization (PMF) method, linked with radiocarbon analysis, to conduct a source apportionment study of $\mathrm{PM}_{2.5}$ at a regional background site in northern China. They found that biomass combustion comprised a significant contribution (19.3\%) to atmospheric $\mathrm{PM}_{2.5}$. Cheng et al. (2013) confirmed the significance of biomass burning in air pollution, finding that approximately $50 \%$ of OC and elemental carbon (EC) in Beijing were associated with biomass burning processes. It is also suggested that more biomass is burned in stoves than in open fields due to China's continued efforts to prevent and control forest fires and the burning of field stalks (Tian et al., 2011; Zhi et al., 2015a; Cheng et al., 2016). Hence, more attention should be paid to the household sector than to open burning as far as biomass-related emissions are concerned in China. In addition, unlike other regions where firewood often plays a major role as a biomass fuel, China has more access to agricultural waste (e.g., maize straw, wheat straw, and rice straw) for household heating and cooking purposes (Huang et al., 2012; Shen et al., 2013; Chen et al., 2015a). This suggests that studies of BrC originating from China's household biomass fuel combustion should consider as many biomass fuel varieties as possible so that the actual characteristics of $\mathrm{BrC}$ emissions can be comprehensively investigated and represented.

The available literature dealing with $\mathrm{BrC}$ from biomass burning in China to date has generally focused on ambient observations (Arola et al., 2011; Chakrabarty et al., 2014; He et al., 2017; Zhao et al., 2018) and modeling (Gustafsson et al., 2009; Feng et al., 2013) of the basic characteristics of atmospheric $\mathrm{BrC}$, such as the concentrations and temporal and spatial distributions. Even though a few studies have collected emission samples at some sources, the objective of these studies was to further understand the general properties of water-soluble organic carbon (WSOC) or methanolsoluble organic carbon (MSOC) (Cheng et al., 2013, 2016; Fan et al., 2016; Lin et al., 2017; Phillips et al., 2017; Huo et al., 2018; Wu et al., 2019; Yan et al., 2020). Consequently, there is a lack of knowledge regarding source emission strengths (emission factors; EFs) and how BrC's role in absorption differs from that of BC (Lack et al., 2012; Healy et al., 2015; Washenfelder et al., 2015; Srinivas, et al., 2016; Zhang et al., 2016) because there is still no standard quantitative method to determine $\mathrm{BrC}$. An intensive study on $\mathrm{BrC}$ from China's household biomass emission sources is therefore necessary to provide insight into both the EFs and light absorption properties of particulate emissions.

In the present study, 11 biomass fuels that are widely used in China were burned in an ordinary stove to simulate domestic burning practices. Particulate emissions were collected on 
quartz filters to measure the $\mathrm{EFs}$ of $\mathrm{BrC}\left(\mathrm{EF}_{\mathrm{BrC}}\right)$ and $\mathrm{BC}$ $\left(\mathrm{EF}_{\mathrm{BC}}\right)$ for China's household biomass burning to investigate the spectral characteristics of absorption by $\mathrm{BrC}$ and estimate the contribution of $\mathrm{BrC}$ to total light absorption by $\mathrm{BC}+\mathrm{BrC}$ across a broad solar spectral range $(350-850 \mathrm{~nm})$. The integrating sphere (IS) method, which was refined in a previous study of residential coal combustion (Sun et al., 2017), was used here to simultaneously quantify $\mathrm{BrC}$ and $\mathrm{BC}$. Furthermore, based on this intensive study of contained biomass burning (in stoves), we extrapolated the results to develop a novel algorithm for estimating the contribution of solar light absorption by $\mathrm{BrC}$ to the sum of $\mathrm{BC}+\mathrm{BrC}$ for perhaps any combustion source. This will help to gain a clearer idea of whether $\mathrm{BC}$ or $\mathrm{BrC}$ dominates the light absorption properties of biomass burning (contained plus open) on a global scale.

\section{Experimental section}

\subsection{Biomass fuels and stoves}

A total of 11 biomass fuels tested in this work were classified into three groups: crop residue (CR, nine types), firewood (FW, one type), and pellet (PF, one type) fuels. The details of these fuels are given in Table S1-I in the Supplement. The stove that we used in this study was a natural draft stove specifically developed for biomass fuels (see Fig. S1 in the Supplement). It is simple and traditional, accounting for approximately half of biomass stoves in China (The World Bank, 2013; Ran et al., 2014).

\subsection{Combustion experiment and sample collection}

The burning and sampling procedures used in this study were in general similar to those described in a previous coal combustion experiment (Sun et al., 2017). Briefly, each biomass fuel was burned in the most commonly used biomass burning stove with a cold start. The amount of fuel was the same as that used in rural households. The fuels were burned in natural combustion processes and rural operation mode. For each biomass fuel, the first batch $(30-300 \mathrm{~g})$ was put into the stove and then ignited with solid alcohol. Sampling and monitoring were immediately initiated. When the combustion began to fade (the first burning cycle, $3-5 \mathrm{~min}$ ), a second batch of the fuel was added to the stove until it had been burned out (the second burning cycle, 3-5 min). Some biomass fuels (e.g., rice and wheat straw) burned so fast that a third or fourth addition was needed to sustain the combustion for an adequate sampling period. Each of the 11 biomass fuels was burned two to three individual times, and the emissions were collected on individual filters. The two to three duplicate samples helped us check the reproducibility and analysis procedure. Background concentrations in ambient air were obtained separately. The modified combustion efficiency (MCE) ranged from $84.0 \%$ (peanut stalk) to almost $100 \%$ (sorghum stalk), with an average of $93.9 \pm 5.9 \%$ (see Table S4), which is generally comparable to the results for residential coal combustion (average MCE values were $88.0 \pm 4.0 \%$ and $82.5 \pm 17.4 \%$ for bituminous chunk and anthracite chunk, respectively, and were $90.1 \pm 1.3 \%$ and $92.8 \pm 1.7 \%$ for all briquettes tested) (Zhang et al., 2020).

Although usually biomass fuels are ignited by gas lighters by ordinary stove users, there are some difficult-to-ignite biomass fuels (e.g., wood) that need to be kindled by some flammable soft materials (e.g., wheat straw, rice straw, or even leaves). Additional emissions from the flammable soft materials are inevitable. In such situations, using solid alcohol to ignite experimental biomass fuels in this study was important because no pollutants other than $\mathrm{CO}_{2}$ and $\mathrm{H}_{2} \mathrm{O}$ were released from alcohol combustion, though the MCE value of each sample might be a little higher than it would have been without the solid alcohol.

A diversion-dilution-sampling system (Fig. S2) was set up to sample and/or monitor the combustion emissions. The dilution factors were set between 3 and 140 to confine the measured $\mathrm{BrC}$ of collected samples in the range of linearity (see Table S1-II). It should be pointed out that the sampling concentration is an important factor in the partitioning of semi-volatile species, which, if collected on the filter, may contribute to $\mathrm{BrC}$ absorption. The quartz-fiber filters used for sampling were pre-baked in a muffle furnace at $450{ }^{\circ} \mathrm{C}$ for $6 \mathrm{~h}$ to remove carbonaceous substances from the filters. Each combustion experiment was repeated two to three times to determine the reproducibility. After sampling, the particleloaded filters were kept in a freezer at $-20^{\circ} \mathrm{C}$ until needed for further analysis.

\subsection{Measurement of $\mathrm{BrC}$ with the integrating sphere method}

The differentiation of $\mathrm{BrC}$ from $\mathrm{BC}$ is a key step toward determining $\mathrm{BrC}$. The mechanism and procedure of the IS method were detailed in a previous study (Sun et al., 2017). Briefly, a $150 \mathrm{~mm}$ IS (manufactured by Labsphere, Inc, see Fig. S3) was built into a UV-Vis-NIR spectrophotometer (ultraviolet-visible-near-infrared; Perkin Elmer Lambda 950). The sphere was internally coated with polytetrafluoroethylene (PTFE), which can reflect more than $99 \%$ of the incident light in the range of $0.2-2.5 \mu \mathrm{m}$ (Wonaschütz et al., 2009). A specially customized transparent quartz cuvette was placed in the center of the sphere using a specially customized cuvette holder. Inside the cuvette was $3 \mathrm{~mL}$ of a $1: 1$ mixture of acetone and an $80: 20$ mixture of water and isopropanol in which a filter punch (rectangle punch, $30 \times 8 \mathrm{~mm}$ ) could be immersed. With this assembly, we scanned through the wavelength range of $350-850 \mathrm{~nm}$ to measure the light absorption by the collected samples. As samples are immersed in a liquid, the absorption enhancement by possible nonabsorbing coatings is negligible (Hitzenberger and Tohno, 2001; Wonaschütz et al., 2009; Sun et al., 2017). 
Two reference materials were used as proxies for $\mathrm{BC}$ and BrC. They were carbon black (CarB) (e.g., Elftex 570, Cabot Corporation) for BC (Fisher, 1970; Andre et al., 1981; Heintzenberg, 1982; Hitzenberger et al., 1996; Wonaschütz et al., 2009) and humic acid sodium salt (HASS) (Acros Organics, no. 68131-04-4) for BrC (Wonaschütz et al., 2009). CarB was used as a proxy for BC in diesel exhaust by Medalia et al. (1983), and HASS was used as a proxy for $\mathrm{BrC}$ from wood combustion by Wonaschütz et al. (2009). In a previous study, CarB and HASS were used as proxies for BC and $\mathrm{BrC}$, respectively, to characterize household coal burning samples by assuming that $\mathrm{BC}$ and $\mathrm{BrC}$ in household coal emissions had the same light-absorbing properties as CarB and HASS, respectively (Sun et al., 2017). In the present study, we extended this logic and assumed that $\mathrm{BC}$ and $\mathrm{BrC}$ in household biomass smoke have the same light-absorbing properties as CarB and HASS, respectively. In other words, the reported $\mathrm{BC}$ and $\mathrm{BrC}$ masses here are essentially CarB$\mathrm{C}$-equivalent and HASS-C-equivalent, respectively, from the perspective of light absorption and are different from those measured by other measurement techniques (e.g., a thermaloptical method or an aethalometer) (Chen et al., 2006; Zhi et al., 2008, 2009; Shen et al., 2013, 2014; Aurell and Gullett, 2013) or reference materials (e.g., fulvic acid, humic acid, or humic-like substances) (Duarte et al., 2007; Lukács, et al., 2007; Baduel et al., 2009, 2010). Although such an assumption is not perfect, researchers can take advantage of these two reference materials to relatively quantify and assess the features (chemical or optical) of $\mathrm{BrC}$ and $\mathrm{BC}$ derived from different combustion sources or regions. It should be noted that the IS method does not depend on an actual chemical separation but on a virtual optical allocation of a mixed absorption signal to $\mathrm{BrC}$ and $\mathrm{BC}$, with HASS and $\mathrm{CarB}$ used as references, respectively.

Calibration curves (see Fig. S4) were plotted for CarB masses from 1.5-90 $\mu \mathrm{g}$ and HASS masses from 3-240 $\mu \mathrm{g}$, according to their respective absorption signals as measured by the IS device, at both 650 and $365 \mathrm{~nm}$ (Sun et al., 2017). The $\mathrm{BrC}$ and $\mathrm{BC}$ masses of the samples were calculated through an iterative procedure based on the different spectral dependences of absorption by $\mathrm{BrC}$ and $\mathrm{BC}$ (see the Supplement and Fig. S4 for the calculation using an iteration procedure). In most cases, 20 iterative calculations will achieve a convergent value for either $\mathrm{BrC}$ or $\mathrm{BC}$. Note that carbon accounts only for $47 \%$ of the mass of HASS, and therefore all measured HASS-equivalent values based on the calibration curves in Fig. S4 were multiplied by 0.47 to obtain the mass of pure brown "carbon" (rather than that of the BrCcontaining compounds).

The CarB used in this study was Elftex 570 from the Cabot Corporation. It had an AAE of 0.91 and mass absorption efficiencies (MAEs) of 27.96 and $20.64 \mathrm{~m}^{2} \mathrm{~g}^{-1}$, respectively, for 365 and $650 \mathrm{~nm}$. The HASS used in this study was from Acros Organics. It had an AAE of 1.86 and MAEs of 6.78 and $0.57 \mathrm{~m}^{2} \mathrm{~g}^{-1}$, respectively, for 365 and $650 \mathrm{~nm}$. Both of materials are similar to actual $\mathrm{BC}$ and $\mathrm{BrC}$ in source emissions or ambient particles (Hitzenberger et al., 1996, 2001, 2006; Reisinger et al., 2008; Wonaschütz et al., 2009; Sun et al., 2017).

\subsection{Calculation methods}

Details of the methods for calculating $\mathrm{EF}_{\mathrm{BrC}}, \mathrm{EF}_{\mathrm{BC}}$, the absorption Ångström exponent (AAE), the wavelengthdependent $\mathrm{BrC}$ contribution to total light absorption $\left(f_{\mathrm{BrC}}(\lambda)\right)$, and the average $\mathrm{BrC}$ contribution to total solar light absorption $\left(F_{\mathrm{BrC}}\right)$ in the range of $350-850 \mathrm{~nm}$ are provided in the Supplement.

\section{Results and discussion}

\subsection{Emission factors of $\mathrm{BrC}$ from biomass fuels}

The calculated EFs of the 11 biomass fuels are presented in Table $1 . \mathrm{EF}_{\mathrm{BrC}}$ varied significantly among biomass fuels. Rape straw had the highest $\mathrm{EF}_{\mathrm{BrC}}\left(7.26 \pm 0.01 \mathrm{~g} \mathrm{~kg}^{-1}\right)$, whereas pellet fuel had the lowest $\left(0.13 \pm 0.06 \mathrm{~g} \mathrm{~kg}^{-1}\right)$. The observed differences may be related to the type of plant (see Fig. 1). We notice that the $\mathrm{EFs}$ of $\mathrm{BrC}$ for herbaceous plants (HPs, the former nine samples in Fig. 1) were higher than those for ligneous plants (LPs, the latter two samples in Fig. 1). This possibly implies that herbaceous plants have a higher potential for forming $\mathrm{BrC}$ than ligneous plants. Although the reason underlying this difference is currently unknown, in view of the lower contents of $\mathrm{C}$ and $\mathrm{H}$ in HPs than in LPs, it seems reasonable to speculate that burning herbaceous plants in household stoves releases less heat than burning ligneous ones, which leads to a lower burning temperature for the former than for the latter and therefore favors the generation of $\mathrm{BrC}$ for the former (Chen et al., 2015b; Wei et al., 2017). In this study, the temperature measured in the stovepipe ( $50 \mathrm{~cm}$ above the stove's upper surface) during HP combustion was $62.9^{\circ} \mathrm{C}$, while during LP combustion it increased to $77.1^{\circ} \mathrm{C}$. Another possible explanation is the distinction in the modified combustion efficiency (MCE) values between LPs and HPs. Our measurements show that HPs tended to have lower MCEs $(93.4 \pm 6.49 \%<95.9 \pm 2.05 \%)$, resulting in a greater chance for the formation of $\mathrm{BrC}$ (Shen et al., 2013). From this perspective, greater importance ought to be attached to herbaceous biomass fuels than to ligneous ones as far as $\mathrm{BrC}$ emissions are concerned.

The $\mathrm{EF}_{\mathrm{BC}}$ values for PFs were the lowest among all the tested biomass fuels; the briquetting effect helped to lower the occurrence of incomplete combustion and thus likely decreased the formation of primary carbonaceous particles (including $\mathrm{BC}$ and $\mathrm{BrC}$ ) (Zhi et al., 2008, 2009). This agrees with the findings of Lei et al. (2018a), as the sum of LAC $(\mathrm{BrC}+\mathrm{BC})$ was observed to decrease after maize straw was transformed to a maize briquette. In view of the virtues of biomass briquetting regarding both air quality (less pollutant 
Table 1. Measured $\mathrm{EF}_{\mathrm{BrC}}$ and $\mathrm{EF}_{\mathrm{BC}}\left(\mathrm{g} \mathrm{kg}^{-1}\right)$ values for household biomass burning.

\begin{tabular}{lrrr}
\hline Biomass fuels & $\mathrm{EF}_{\mathrm{BrC}}$ & $\mathrm{EF}_{\mathrm{BC}}$ & $R_{\mathrm{BrC} / \mathrm{BC}}$ \\
\hline Rape straw & $7.26 \pm 0.01$ & $2.54 \pm 0.01$ & $2.86 \pm 0.02$ \\
Rice straw & $2.50 \pm 3.06$ & $0.31 \pm 0.25$ & $8.06 \pm 6.67$ \\
Wheat straw & $1.25 \pm 0.07$ & $0.13 \pm 0.04$ & $9.62 \pm 5.17$ \\
Cotton straw & $0.89 \pm 0.51$ & $0.10 \pm 0.02$ & $8.91 \pm 2.99$ \\
Bean straw & $0.57 \pm 0.12$ & $0.09 \pm 0.04$ & $6.41 \pm 2.21$ \\
Corncob & $0.56 \pm 0.55$ & $0.056 \pm 0.02$ & $10.01 \pm 8.77$ \\
Peanut stalk & $0.54 \pm 0.15$ & $0.13 \pm 0.054$ & $4.15 \pm 1.42$ \\
Sorghum stalk & $0.45 \pm 0.32$ & $0.30 \pm 0.054$ & $1.51 \pm 0.39$ \\
Maize straw & $0.45 \pm 0.76$ & $0.053 \pm 0.014$ & $8.49 \pm 4.97$ \\
Pine & $0.27 \pm 0.29$ & $0.034 \pm 0.017$ & $7.94 \pm 3.41$ \\
Pellet fuels & $0.13 \pm 0.06$ & $0.023 \pm 0.037$ & $5.65 \pm 2.58$ \\
\hline Geometric mean & $0.71(0.24,2.09)$ & $0.12(0.033,0.436)$ & $5.90(3.26,10.68)$ \\
\hline
\end{tabular}

Note: the last row is expressed as the geometric mean (lower limit, upper limit). The lower and upper limits are calculated via the geometric mean divided or multiplied by the geometric standard deviation (GSD). The GSDs for $\mathrm{EF}_{\mathrm{BrC}}, \mathrm{EF}_{\mathrm{BC}}$, and $R_{\mathrm{BrC} / \mathrm{BC}}$ are $2.95,3.63$, and 1.81 , respectively.

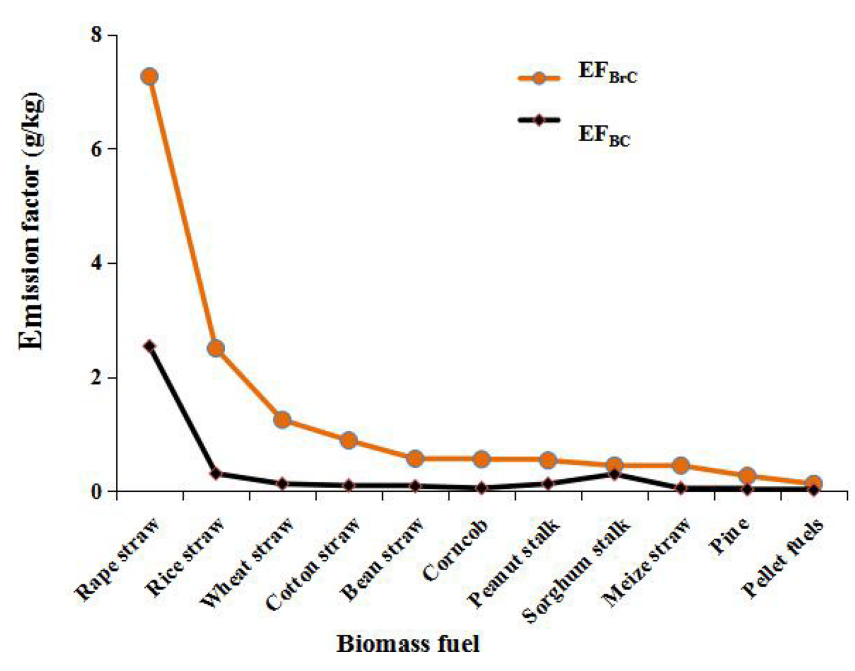

Figure 1. EFs of tested biomass fuels.

emissions) and climate change mitigation (carbon-neutral), the present study identified an additional benefit of biomass briquetting in climate change mitigation because of the reduction in emissions of LAC (Sun and Xu, 2012; Arshanitsa et al., 2016; Chen et al., 2016).

Geometrically averaging the $\mathrm{EF}_{\mathrm{BrC}}$ values over all tested biomass fuels yielded a value of $0.71 \mathrm{~g} \mathrm{~kg}^{-1}$. This value was comparable to the obtained $\mathrm{EF}_{\mathrm{BrC}}$ for forest fires in the southeastern United States, measured with an AE52 aethalometer (1.0-1.4 $\mathrm{g} \mathrm{kg}^{-1}$, BC-equivalent) (Aurell and Gullett, 2013). In another study by Schmidl et al. (2008), the IS method was used to measure the $\mathrm{BrC}$ and $\mathrm{BC}$ emission characteristics of open fires with three kinds of leaves. As $\mathrm{BrC}$ accounted for $18.5 \%(w / w)$ of the $\mathrm{PM}_{10}$ of leaf smoke (Schmidl et al., 2008) and as the $\mathrm{PM}_{10}$ EF for biomass fuel combustion (given by Cao et al., 2011) is $5.77 \mathrm{~g} \mathrm{~kg}^{-1}$ (field burn- ing), the $\mathrm{EF}_{\mathrm{BrC}}$ can be inferred for open fires with three kinds of leaves, i.e., $1.07 \mathrm{~g} \mathrm{~kg}^{-1}$. This value is also comparable to the averaged $\mathrm{EF}_{\mathrm{BrC}}$ obtained in this study. In addition, the current $\mathrm{EF}_{\mathrm{BrC}}$ average value, $0.71 \mathrm{~g} \mathrm{~kg}^{-1}$, was closer to the values obtained for the combustion of anthracite chunks $\left(1.08 \pm 0.80 \mathrm{~g} \mathrm{~kg}^{-1}\right)$ and anthracite briquettes $\left(1.52 \pm 0.16 \mathrm{~g} \mathrm{~kg}^{-1}\right)$ than to those obtained for the combustion of bituminous chunks $\left(8.59 \pm 2.70 \mathrm{~g} \mathrm{~kg}^{-1}\right)$ and bituminous briquettes $\left(4.01 \pm 2.19 \mathrm{~g} \mathrm{~kg}^{-1}\right)$ (Sun et al., 2017). This suggests the specific importance of the residential combustion of bituminous coals in $\mathrm{BrC}$ emissions.

Figure 1 compares $\mathrm{EF}_{\mathrm{BrC}}$ and $\mathrm{EF}_{\mathrm{BC}}$. The ratios of $\mathrm{EF}_{\mathrm{BrC}}$ to $\mathrm{EF}_{\mathrm{BC}}\left(R_{\mathrm{BrC} / \mathrm{BC}}\right)$ varied greatly among various biomass fuels, and corncobs and sorghum stalks gave the highest (10.0) and lowest (1.5) $R_{\mathrm{BrC} / \mathrm{BC}}$ values, respectively. Generally, the large range of $R_{\mathrm{BrC} / \mathrm{BC}}$ values among different biomass fuels is attributable to the individual biomass fuels themselves, or more concretely their chemical composition and physical structure. Here both $\mathrm{BrC}$ and $\mathrm{BC}$ were products of incomplete combustion of biomass fuels (Andreae and Gelencsér, 2006; Yan et al., 2015). Different biomass fuels were composed of different organics that had different combustion performances (Reid et al., 2005; Saleh et al., 2014); meanwhile, different biomass fuels were also different in densities and moisture contents (Shen et al., 2014; Jacobson et al., 2015), which also have a potential influence on combustion performance. The combustion performance relates to something like the combustion speed and temperature, both of which are important to the formation of $\mathrm{BrC}$ and $\mathrm{BC}$. Usually a low combustion temperature is more favorable for $\mathrm{BrC}$ formation and a relatively high combustion temperature is more favorable for BC formation (Chen and Bond, 2010; Bond et al., 2013; Shen et al., 2014). This makes the generation processes of $\mathrm{BC}$ and $\mathrm{BrC}$ often not synchronous but opposite in 
trend, which may account for wide variations of $R_{\mathrm{BrC} / \mathrm{BC}}$ for different fuels in combustion conditions.

More importantly, each of the 11 biomass fuels tested in this study had a higher $\mathrm{EF}_{\mathrm{BrC}}$ than $\mathrm{EF}_{\mathrm{BC}}$; that is, the ratios of $\mathrm{EF}_{\mathrm{BrC}}$ to $\mathrm{EF}_{\mathrm{BC}}\left(R_{\mathrm{BrC} / \mathrm{BC}}\right)$ were all $>1$. The average $R_{\mathrm{BrC} / \mathrm{BC}}$ over all biomass fuels was $6.7 \pm 2.7$. Kirchstetter et al. (2004) measured light absorption with filter-based aerosol samples from biomass burning before and after acetone treatment (which removed OC). They found that $50 \%$ of total light absorption was attributable to OC. In view of the much smaller average absorption efficiency of $\mathrm{BrC}$ relative to that of BC (for example, Yang et al., 2009, reported that the MAEs at $550 \mathrm{~nm}$ were $9.5,0.5$, and $0.03 \mathrm{~m}^{2} \mathrm{~g}^{-1}$ for $\mathrm{BC}, \mathrm{BrC}$, and dust, respectively), the contribution of $\mathrm{BrC}$ to the mass of total LAC is undoubtedly far higher than that of $\mathrm{BC}$, an inference which is consistent with the present study.

\subsection{Spectral dependence of absorption}

AAE represents the spectral dependence of light absorption efficiency (Martinsson et al., 2015; Washenfelder et al., 2015; Yan et al., 2015). Usually, the AAE is close to 1.0 (Lack and Langridge, 2013; Laskin et al., 2015) for BC with a pronounced graphitic structure. This has been demonstrated by several studies on diesel exhaust and urban particulate matter (Rosen et al., 1978; Horvath, 1997). However, the existence of $\mathrm{BrC}$ in aerosols makes the mass absorption efficiency (MAE) increase more strongly towards shorter wavelengths due to a larger $\mathrm{AAE}$ for $\mathrm{BrC}$ than for $\mathrm{BC}$, which makes the AAEs of BrC-containing carbonaceous aerosols larger than 1 (Chakrabarty et al., 2013; Yan et al., 2015).

In this study, the measured AAE values for smoke from the combustion of the 11 biomass fuels (see Table S2-I) ranged from 1.38 (sorghum stalk) to 2.98 (rice straw), with an average of $2.46 \pm 0.53$. This suggests the existence of $\mathrm{BrC}$ in the particulate emissions. As a comparison, in a previous study that used the IS method for household coal combustion (Sun et al., 2017), average AAE values of $2.55 \pm 0.44$ for coal briquettes and $1.30 \pm 0.32$ for coal chunks were obtained (Sun et al., 2017). Cai et al. (2014) observed an AAE value of $3.02 \pm 0.18$ for the open burning of wheat straw and of $1.43 \pm 0.26$ for household coal burning using an aethalometer (AE31). Other studies have reported a wide range of AAE values, dependent on fuels, combustion conditions, aging effects after emission, the wavelengths covered, and the pretreatment experienced (see Table S3).

However, as AAE $>1$ for aerosol samples theoretically results from $\mathrm{BrC}$ instead of BC (Martinsson et al., 2015; Washenfelder et al., 2015; Zhi et al., 2015b; Yuan et al., 2016), the wide range of AAE literature values is believed to be linked to variation in the ratio of $\mathrm{BrC}$ to $\mathrm{BC}\left(R_{\mathrm{BrC} / \mathrm{BC}}\right)$. That is, the increase in $R_{\mathrm{BrC} / \mathrm{BC}}$ theoretically leads to an increase in AAE (Lack and Langridge, 2013). Indirect support for this interpretation can be inferred from the existing literature. For example, Saleh et al. (2014) noticed that the ef-

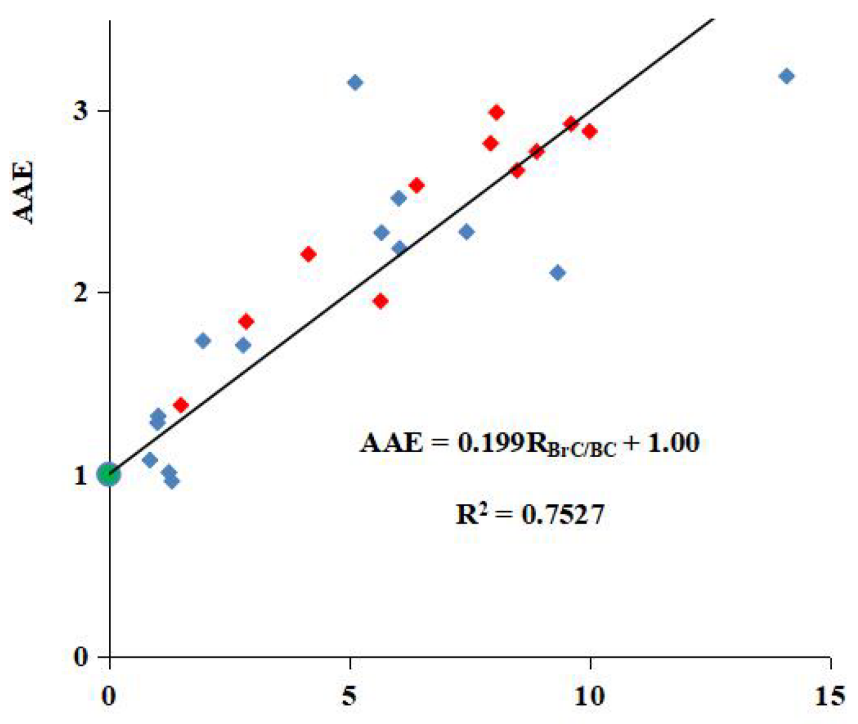

$\mathbf{R B r C} / \mathbf{B C}$

Figure 2. Relationship between $\mathrm{AAE}$ and the $\mathrm{EF}_{\mathrm{BrC}} / \mathrm{EF}_{\mathrm{BC}}$ ratio $\left(R_{\mathrm{BrC} / \mathrm{BC}}\right)$ for both biomass fuel (red) and coal (blue). The intercept is designated as 1.0 to echo the conventionally accepted notion that the $\mathrm{AAE}$ for pure $\mathrm{BC}$ (i.e., $R_{\mathrm{BrC} / \mathrm{BC}}=0$ ) is 1.0 .

fective absorptivity of organic aerosol in biomass burning emissions could be parameterized as a function of the ratio of $\mathrm{BC}$ to $\mathrm{OC}$ (an umbrella term that also includes $\mathrm{BrC}$ ). Costabile et al. (2017) found that the AAE (467-660 nm) in the atmosphere of the urban Po Valley was positively correlated with the ratio of organic aerosol $(\mathrm{OA})$ to $\mathrm{BC}\left(R^{2}=\right.$ $0.78)$ rather than with $\mathrm{OA}$ concentrations alone. The more persuasive scenario concerns WSOC, which is free of BC $\left(R_{\mathrm{BrC} / \mathrm{BC}}=+\infty\right)$; for this scenario the $\mathrm{AAE}$ reaches its maximum (see also Table S3).

The EFs and AAEs of 11 biomass fuels used in this study and the EFs and AAEs of seven coals used in a previous study (Sun et al., 2017) are collated and arranged in a scatter plot in Fig. 2. Obviously, the AAE values are positively correlated with $R_{\mathrm{BrC} / \mathrm{BC}}$ values. Considering that the $\mathrm{AAE}$ for pure $\mathrm{BC}$ (i.e., $R_{\mathrm{BrC} / \mathrm{BC}}=0$ ) is conventionally accepted as 1.0 , we set the intercept to 1.0 to comply with the theoretical constraint. The relation between $\mathrm{AAE}$ and $R_{\mathrm{BrC} / \mathrm{BC}}$ can be expressed in Eq. (1).

$\mathrm{AAE}=0.199 R_{\mathrm{BrC} / \mathrm{BC}}+1.00\left(R^{2}=0.7527\right)$

Equation (1) supports the $\mathrm{AAE}-R_{\mathrm{BrC} / \mathrm{BC}}$ relation in a quantitative way.

\subsection{Light absorption by $\mathrm{BrC}$ from household biomass combustion in household stoves}

With the $\mathrm{EF}_{\mathrm{BrC}}$ and $\mathrm{EF}_{\mathrm{BC}}$ obtained in the present study, as well as publicly available consumption data on household biomass fuels, China's $\mathrm{BrC}$ and $\mathrm{BC}$ emissions from biomass 


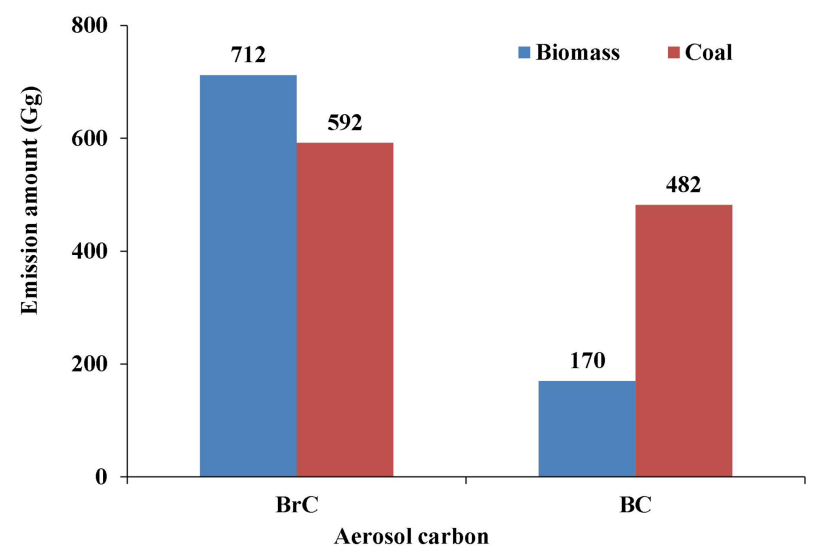

Figure 3. Comparison of $\mathrm{BrC}$ and $\mathrm{BC}$ emissions between biomass burning and coal combustion from China's household sector in 2013.

fuels burned in household stoves can be calculated following the method described in the Supplement. In 2013, the biomass fuels consumed in China comprised $695 \mathrm{Tg}(1 \mathrm{Tg}=$ $10^{12} \mathrm{~g}$ ) for household cooking and heating purposes ( $\mathrm{Lu}$ et al., 2011; Tian et al., 2011; NBSC, 2014). The calculated BrC emissions were as high as $712 \mathrm{Gg}$. We acknowledge that the calculated emissions contained large uncertainties resulting from the amounts and forms of different types of biomass fuels and the representativity of $\mathrm{BrC}$ EFs measured in this study. Improved fuel consumption data and EFs will lead to better future emission estimates. South Asian funeral pyres released $92 \mathrm{Gg}$ of $\mathrm{BrC}$ in 2011 (calculated with the double IS system method) (Chakrabarty et al., 2014), which is much less than that from China's household biomass combustion. This implies a clear need to control $\mathrm{BrC}$ emissions from household biomass burning in China.

Figure 3 compares the emissions of $\mathrm{BrC}$ and $\mathrm{BC}$ from biomass fuels in this study and from coals as reported in a previous study (Sun et al., 2017). It is obvious that $\mathrm{BrC}$ emissions have always been higher than BC emissions for both household biomass fuels and coals, which is attributable to the higher $\mathrm{EF}_{\mathrm{BrC}}$ than $\mathrm{EF}_{\mathrm{BC}}$ for both biomass fuels and coals. It is also interesting to note that, for $\mathrm{BrC}$, biomass fuel dominated, whereas for $\mathrm{BC}$, coal was more important. This suggests the relative importance of biomass fuels in controlling BrC.

The large calculated emissions of $\mathrm{BrC}$ for China's household biomass fuel combustion represent a strong argument for including $\mathrm{BrC}$ in estimating total light absorption by emissions from burning biomass. Here, we used $f_{\mathrm{BrC}}(\lambda)$ to represent the fraction of $\mathrm{BrC}$ absorption in the sum of light absorption by $\mathrm{BrC}+\mathrm{BC}$ at individual wavelengths of the scanned spectral ranges $(350-850 \mathrm{~nm})$, as measured with the IS. A detailed description of the theory and method for calculating $f_{\mathrm{BrC}}(\lambda)$ is given in the Supplement. The detailed values of $f_{\mathrm{BrC}}$ for biomass fuel and coal (Sun et al., 2017) from

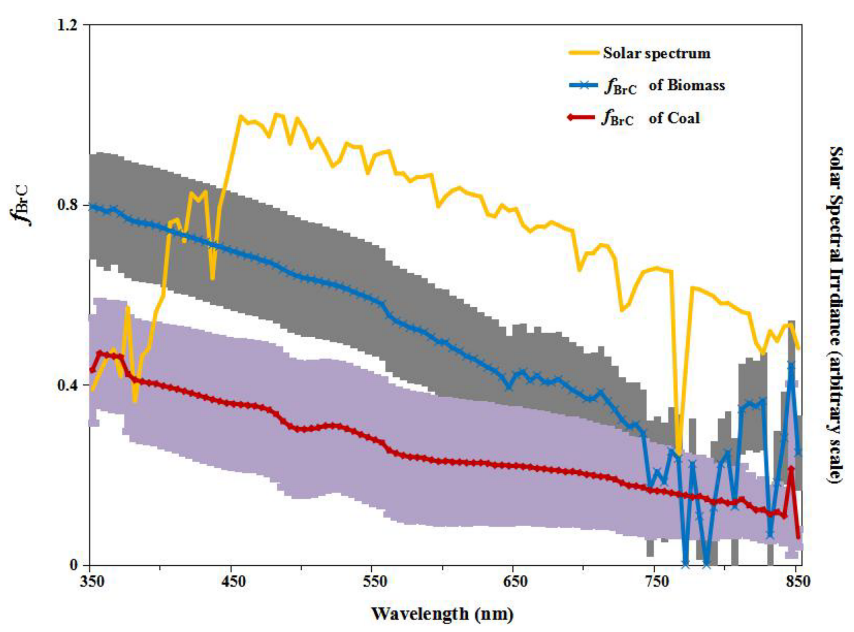

Figure 4. Ratios of light absorption by $\mathrm{BrC}$ to total absorption by total mass with respect to China's household biomass and coal burning. Note: the ratio is expressed as $f_{\mathrm{BrC}}$ and was calculated in accordance with the method described in the Supplement. The yellow line is the clear-sky global horizontal solar spectrum at the Earth's surface for one optical air mass in relative units (Levinson et al., 2010; Chakrabarty et al., 2014).

$350-850 \mathrm{~nm}$ are given in Table S2-II. The results of $f_{\mathrm{BrC}}(\lambda)$ for biomass fuels in this study are plotted in Fig. 4 (blue line).

Evidently, the $f_{\mathrm{BrC}}(\lambda)$ increased towards shorter wavelengths: the $f_{\mathrm{BrC}}(\lambda)$ at $850 \mathrm{~nm}$ was 0.25 , whereas the $f_{\mathrm{BrC}}(\lambda)$ at $350 \mathrm{~nm}$ increased to 0.8 . In addition to the spectrally dependent $f_{\mathrm{BrC}}(\lambda)$ for biomass fuels, Fig. 4 also presents the spectrally dependent $f_{\mathrm{BrC}}(\lambda)$ values for coal (red line) as obtained in a previous study (Sun et al., 2017). The lowest value of $f_{\mathrm{BrC}}(\lambda)$ for coal occurred at $0.061(850 \mathrm{~nm})$, and the highest value occurred at $0.47(355 \mathrm{~nm})$. The average $f_{\mathrm{BrC}}(\lambda)$ for coal was 0.26 , which is distinctly lower than that for biomass fuels. This difference in $f_{\mathrm{BrC}}$ between coal and biomass smoke can be explained by the difference in $R_{\mathrm{BrC} / \mathrm{BC}}$ between coal and biomass smoke. It is necessary to exercise caution when attributing absorption to $\mathrm{BrC}$ vs. $\mathrm{BC}$ based on wavelength dependence (expressed as AAE). For example, Lack and Langridge (2013) found that the uncertainties in attributed $\mathrm{BrC}$ absorption might be $\pm 33 \%$ with $\mathrm{BrC}$ contributing between $23 \%$ and $41 \%$ to the total absorption (assuming an absorption measurement uncertainty of $\pm 5 \%$ ).

Integrating $f_{\mathrm{BrC}}(\lambda)$ over the solar spectrum results in $F_{\mathrm{BrC}}$, which represents the fraction of solar radiance $\mathrm{ab}$ sorbed by $\mathrm{BrC}$ relative to the total absorption by $\mathrm{BC}+$ $\mathrm{BrC}$ (refer to the Supplement for the method of calculation for $\left.F_{\mathrm{BrC}}\right)$. The standard solar spectrum is also plotted in Fig. 4 (yellow line) as a contrast and reference. A value of $0.508(0.471-0.542)$ was obtained for the $F_{\mathrm{BrC}}$ of household biomass fuels across the wavelength range of $350-850 \mathrm{~nm}$, which was nearly twice that of household coal combustion (0.265) in China (Sun et al., 2017). 


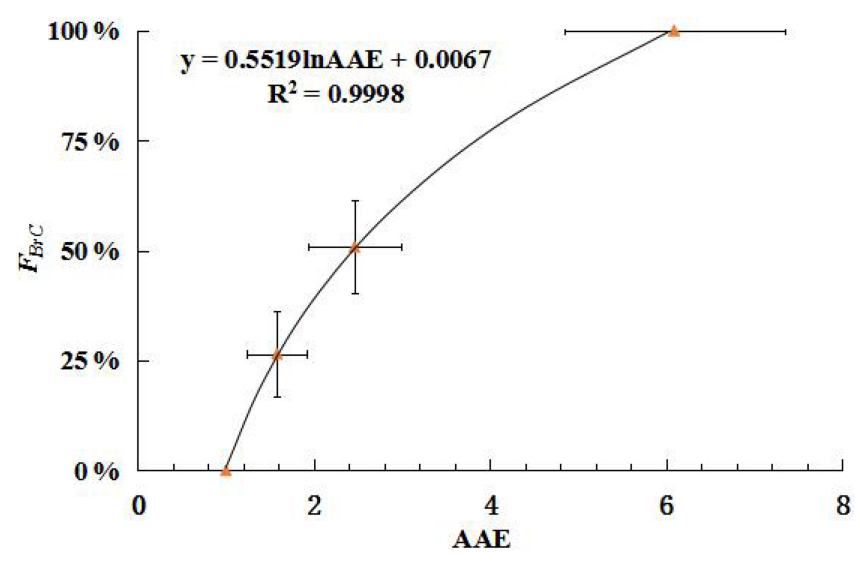

Figure 5. Relationship between $F_{\mathrm{BrC}}$ and AAE.

\subsection{Extrapolation towards a novel algorithm for estimating the relative contribution of $\mathrm{BrC}$}

As $F_{\mathrm{BrC}}$ is defined as the ratio of solar light absorption by $\mathrm{BrC}$ to that by $\mathrm{BrC}+\mathrm{BC}$ across $350-850 \mathrm{~nm}$, it is physi-

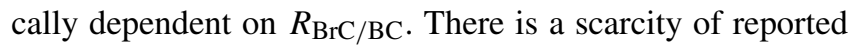
$R_{\mathrm{BrC} / \mathrm{BC}}$ values, whereas conversely $\mathrm{AAE}$ is frequently reported in the existing literature. Therefore, the logarithmical function that can be fitted to the relationship between $R_{\mathrm{BrC} / \mathrm{BC}}$ and $\mathrm{AAE}$ (Fig. 2) can be used for the practical application of expressing $F_{\mathrm{BrC}}$ as a function of AAE.

To construct the function for $F_{\mathrm{BrC}}$, with $\mathrm{AAE}$ as the independent variable, we managed to gather four pairs of $F_{\mathrm{BrC}}$ vs. AAE values. Two of these pairs were based on theory. For pure $\mathrm{BC}$ (free of $\mathrm{BrC}$ ), $\mathrm{AAE}$ and $F_{\mathrm{BrC}}$ were 1.0 (Lack and Langridge, 2013; Laskin et al., 2015; Yan et al., 2015; Zhang et al., 2020) and 0.0, respectively, whereas for samples of pure $\mathrm{BrC}$ (free of $\mathrm{BC}$ ), we averaged over the $\mathrm{AAE}$ values in the literature for WSOC or MSOC (free of BC), thus obtaining an AAE value of $6.09 \pm 1.45$ (Hoffer et al., 2006; Hecobian et al., 2010; Voisin et al., 2012; Srinivas and Sarin, 2013, 2014; Srinivas et al., 2016; Lei et al., 2018b) (Table S3I). The other two pairs of $F_{\mathrm{BrC}}$ vs. AAE values were obtained from our previous and current studies. The previous study (Sun et al., 2017) demonstrated that when AAE was $1.58, F_{\mathrm{BrC}}$ was 0.265 . In the present study, as mentioned in Sect. 3.3, an AAE of 2.46 led to an $F_{\mathrm{BrC}}$ of 0.508 . These four $F_{\mathrm{BrC}}$ vs. AAE pairs were used to construct the relationship between $F_{\mathrm{BrC}}$ and AAE (Fig. 5). It should be noted that we used the average value for each of the latter three points so that all four points in Fig. 5 were given equal weight (25\%). A logarithmical equation was established between $F_{\mathrm{BrC}}$ and AAE, with a very high correlation coefficient.

$$
\begin{aligned}
F_{\mathrm{BrC}}= & 0.5519 \ln \mathrm{AAE}+0.0067 \\
& \cdot\left(R^{2}=0.999,1 \leq \mathrm{AAE} \leq 6.09\right)
\end{aligned}
$$

Equation (2) provides a novel algorithm for deriving $F_{\mathrm{BrC}}$ from AAE without consideration of the process details for perhaps any kind of combustion source. Uncertainties are unavoidable due to the uncertainties of each of the points (Lack and Langridge, 2013; Sun et al., 2017; references in Table S3-I). For example, Lack and Langridge (2013) estimated that the uncertainty in short-wavelength absorption by $\mathrm{BC}$, determined by extrapolation using an $\mathrm{AAE}=1$, ranged from $+7 \%$ to $-22 \%$. Equation (2) helps to broaden insight into biomass burning issues from contained conditions to open conditions. The results of $F_{\mathrm{BrC}}$ for open fresh emissions from open biomass burning $\left(F_{\mathrm{BrC}-\text { open }}\right)$ vary in the literature, and most have values below 0.50 (or $50 \%$ ) (Lack et al., 2012; Healy et al., 2015; Washenfelder et al., 2015; Srinivas, et al., 2016). We collected $\mathrm{AAE}_{\text {-open }}$ data from available journal articles and included them in Table S3-II. The calculated av-

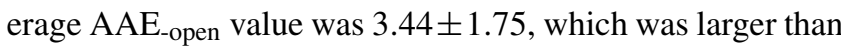
the $\mathrm{AAE}_{\text {-contained }}$ value obtained in this study $(2.46 \pm 0.53)$. Substitution of the $\mathrm{AAE}_{\text {-open }}$ value $(3.44 \pm 1.75)$ into Eq. (2) leads to a value of 0.685 for $F_{\mathrm{BrC}-\text { open }}$, which is higher than the $F_{\mathrm{BrC}}$ for contained combustion $\left(F_{\mathrm{BrC}-\text { contained }}\right)(0.508)$, indicating that BrC's light absorption was more dominant in open biomass burning emissions than in contained biomass burning emissions.

Assuming that the $\mathrm{AAE}_{\text {-contained }}$ and $\mathrm{AAE}_{\text {-open }}$ identified above apply to global biomass burning, we can now assess BrC's role in biomass burning globally (contained + open) $\left(F_{\text {BrC-entire }}\right)$, in combination with the respective shares of open and contained burning. Previous studies show that the annual open and contained biomass burning amounts are $5953 \mathrm{Tg}$ (Wiedinmyer et al., 2011) and $2457 \mathrm{Tg}$ (Fernandes et al., 2007), respectively. This implies that open biomass burning represents $71 \%$ of total biomass burning and contained biomass burning represents $29 \%$. Subsequently, the $F_{\mathrm{BrC}-\text { entire }}$ can be calculated according to the following equation.

$$
\begin{aligned}
F_{\text {BrC-entire }}= & 0.29 \times\left(0.5519 \ln \mathrm{AAE}_{\text {-contained }}+0.0067\right) \\
& +0.71 \times\left(0.5519 \ln \mathrm{AAE}_{\text {-open }}+0.0067\right)
\end{aligned}
$$

With Eq. (3), the distribution of $F_{\mathrm{BrC}-\text { entire was simulated }}$ through the Monte Carlo approach, as shown in Fig. 6. The $F_{\text {BrC-entire was }} 0.644$ on average, with an $80 \%$ probability that it ranges $0.585-0.699$. Particularly, the probability of

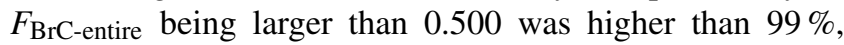
corroborating the leading role of $\mathrm{BrC}$ in absorption by solar light for total biomass burning emissions. Kirchstetter and Thatcher (2012) calculate that OC from wood smoke could account for $14 \%$ of solar radiation absorbed by wood smoke in the atmosphere (integrated over the solar spectrum from 300 to $2500 \mathrm{~nm}$ ); $14 \%$ is much smaller than our data with $F_{\mathrm{BrC} \text {-entire }}=64.4 \%$ because Kirchstetter and Thatcher (2012) only focus on rural California wintertime wood combustion, but we calculated the global contribution to absorption by $\mathrm{BrC}$ originating from biomass combustion. 


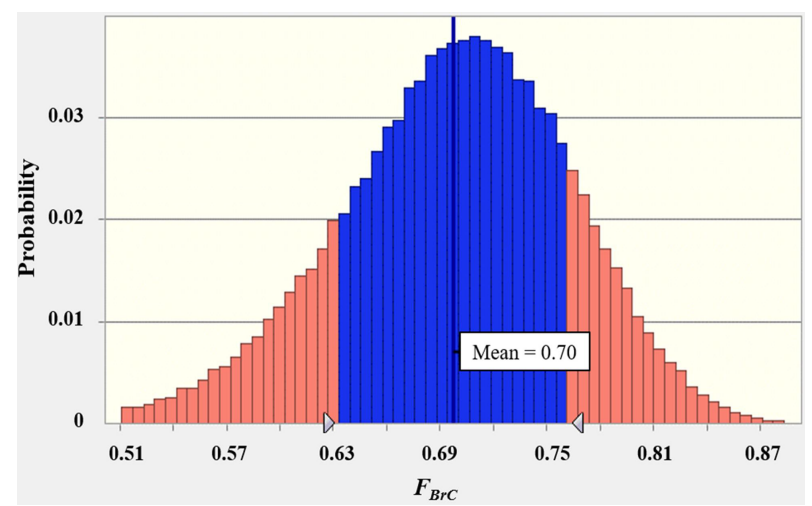

Figure 6. The probability distribution of calculated $F_{\mathrm{BrC} \text {-entire }}$.

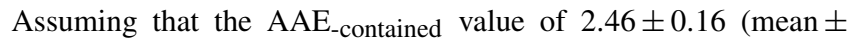
$\mathrm{SD}$ of the means) and $\mathrm{AAE}_{\text {-open }}$ value of $3.44 \pm 0.42$ (mean \pm $\mathrm{SD}$ of the means) apply to global biomass burning, the combined value for all biomass burning $\left(F_{\mathrm{B} \text {-entire }}\right)$ can be calculated as $F_{\mathrm{BrC} \text {-entire }}=0.71 \times\left(0.5519 \ln \mathrm{AAE}_{\text {-open }}+0.0067\right)+0.29 \times$ $\left(0.5519 \ln \mathrm{AAE}_{\text {-contained }}+0.0067\right)$.

\section{Conclusions}

The optical IS approach was used to distinguish $\mathrm{BrC}$ from $\mathrm{BC}$ in filter samples of the emissions of 11 types of biomass after burning in a typical stove. The measured average EF of household biomass fuels for $\mathrm{BrC}$ was $0.71 \mathrm{~g} \mathrm{~kg}^{-1}$, and the calculated annual $\mathrm{BrC}$ emissions from China's household biomass burning amounted to $712 \mathrm{Gg}$. This is higher than the emissions from China's household coal combustion $(592 \mathrm{Gg})$. Moreover, it was observed that $\mathrm{BrC}$ contributed to approximately half of all light absorption by $\mathrm{BC}+\mathrm{BrC}$ across the strongest solar spectral range $\left(350-850 \mathrm{~nm} ; F_{\mathrm{BrC}}=\right.$ $50.8 \%)$. A novel relationship was constructed $\left(F_{\mathrm{BrC}}=\right.$ $0.5519 \ln (\mathrm{AAE})+0.0067, R^{2}=0.999$ ), which can simplify the calculation of $F_{\mathrm{BrC}}$ by using AAE. With this mathematical relationship, we calculated the $F_{\mathrm{BrC}}$ values for open biomass burning $\left(F_{\mathrm{BrC} \text {-open }}=70.1 \%\right)$ and all biomass burning $\left(F_{\mathrm{BrC} \text {-entire }}=64.4 \%\right)$, thereby establishing the dominant role of $\mathrm{BrC}$ in biomass burning absorption. From this perspective, we recommend that it is necessary to include $\mathrm{BrC}$ in the climate discussion, particularly concerning biomass burning (contained and open). The algorithm developed here omits the long procedures of chemical treatment, optical measurement, and tedious calculations, and it provides a scheme for estimating the contribution of $\mathrm{BrC}$ relative to $\mathrm{BC}$ in perhaps any combustion process with LAC emissions.

Data availability. The research data can be accessed on request to the corresponding author (zhigr@craes.org.cn).

Supplement. The supplement related to this article is available online at: https://doi.org/10.5194/acp-21-2329-2021-supplement.
Author contributions. GZ and YiC designed the research together. JS, YZ, WJ, LW, and ZZ carried out the field measurements in 2015. JS and YZ analyzed the data and wrote the paper. YuC, LY, DH, YQ, JX, XX, XZ, XY, and YaC helped with the interpretation of the results. $\mathrm{RH}$ provided input for the data analysis and presentation as well as comments and input for the text. ZL, RC, WX, WY, YS, $\mathrm{CW}$, and $\mathrm{CT}$ revised the original paper. All authors contributed to the development of the paper.

Competing interests. The authors declare that they have no conflict of interest.

Financial support. This research has been supported by the National Natural Science Foundation (grant no. 41977309), research results of the 13th 5-year plan for social sciences in Jiangxi Province, China (grant no. 19ZK34), the National Key Research \& Development Plan (grant no. 2017YFC0213001), the Special Project of Fundamental Research Funds of the Chinese Research Academy of Environmental Sciences (grant no. JY41373131), the Chinese-Norwegian Project on Emissions, Impacts, and Control Policies for Black Carbon and its Co-benefits in Northern China (grant no. CHN-2148-19/0029), and topics of the Jiangxi Sports Bureau, China (grant no. 2018021).

Review statement. This paper was edited by Sergey A. Nizkorodov and reviewed by two anonymous referees.

\section{References}

Andre, K., Dlugi, R., and Schantz, G.: Absorption of visible radiation by atmospheric aerosol particles in fog and cloud water residues, J. Atmos. Sci., 38, 141-155, https://doi.org/10.1175/15200469(1981)038<0141:aovrba>2.0.co;2, 1981.

Andreae, M. O. and Gelencsér, A.: Black carbon or brown carbon? The nature of light-absorbing carbonaceous aerosols, Atmos. Chem. Phys., 6, 3131-3148, https://doi.org/10.5194/acp-63131-2006, 2006.

Arola, A., Schuster, G., Myhre, G., Kazadzis, S., Dey, S., and Tripathi, S. N.: Inferring absorbing organic carbon content from AERONET data, Atmos. Chem. Phys., 11, 215-225, https://doi.org/10.5194/acp-11-215-2011, 2011.

Arshanitsa, A., Akishin, Y., Zile, E., Dizhbite, T., Solodovnik, V., and Telysheva, G.: Microwave treatment combined with conventional heating of plant biomass pellets in a rotated reactor as a high rate process for solid biofuel manufacture, Renew. Energ., 91, 386-396, https://doi.org/10.1016/j.renene.2016.01.080, 2016.

Aurell, J. and Gullett, B. K.: Emission factors from aerial and ground measurements of field and laboratory forest burns in the southeastern US: $\mathrm{PM}_{2.5}$, black and brown carbon, VOC, and PCDD/PCDF, Environ. Sci. Technol., 47, 8443-8452, https://doi.org/10.1021/es402101k, 2013.

Baduel, C., Voisin, D., and Jaffrezo, J. L.: Comparison of analytical methods for Humic Like Substances (HULIS) measurements 
in atmospheric particles, Atmos. Chem. Phys., 9, 5949-5962, https://doi.org/10.5194/acp-9-5949-2009, 2009.

Baduel, C., Voisin, D., and Jaffrezo, J.-L.: Seasonal variations of concentrations and optical properties of water soluble HULIS collected in urban environments, Atmos. Chem. Phys., 10, 40854095, https://doi.org/10.5194/acp-10-4085-2010, 2010.

Bond, T., Doherty, S., Fahey, D., Forster, P., Berntsen, T., DeAngelo, B., Flanner, M., Ghan, S., Kärcher, S., Koch, D., Kinne, S., Kondo, Y., Quinn, P., Sarofim, M., Schultz, M., Schulz, M., Venkataraman, C., Zhang, H., Zhang, S., Bellouin, N., Guttikunda, S., Hopke, P., Jacobson, M., Kaiser, J., Klimont, Z., Lohmann, U., Schwarz, J., Shindell, D., Storelvmo, T., Warren, S., and Zender, C.: Bounding the role of black carbon in the climate system: A scientific assessment, J. Geophys. Res.-Atmos., 118, 5380-5552, https://doi.org/10.1002/jgrd.50171, 2013.

Bosch, C., Andersson, A., Kirillova, E. N., Budhavant, K., Tiwari, S., Praveen, P. S., Russell, L. M., Beres, N. D., Ramanathan, V., and Gustafsson, Ö.: Source-diagnostic dual-isotope composition and optical properties of water-soluble organic carbon and elemental carbon in the South Asian outflow intercepted over the Indian Ocean, J. Geophys. Res.-Atmos., 119, 11743-11759, https://doi.org/10.1002/2014jd022127, 2014.

Budisulistiorini, S. H., Riva, M., Williams, M., Chen, J., Itoh, M., Surratt, J. D., and Kuwata, M.: Light-absorbing brown carbon aerosol constituents from combustion of Indonesian peat and biomass, Environ. Sci. Technol. Lett., 51, 4415-4423, https://doi.org/10.1021/acs.est.7b00397, 2017.

Cai, J., Zhi, G., Chen, Y., Meng, F., Xue, Z., Li, J., and Fang, Y.: A preliminary study on brown carbon emissions from open agricultural biomass burning and residential coal combustion in China, Res. Environ. Sci., 27, 455-461, https://doi.org/10.13198/j.issn.1001-6929.2014.05.01, 2014 (in Chinese).

Cao, G., Zhang, X., Gong, S., An, X., and Wang, Y.: Emission inventories of primary particles and pollutant gases for China, Chinese Sci. Bull., 56, 781-788, https://doi.org/10.1007/s11434011-4373-7, 2011.

Chakrabarty, R. K., Arnold, I. J., Francisco, D. M., Hatchett, B., Hosseinpour, F., Loria, M., Pokharel, A., and Woody, B. M.: Black and brown carbon fractal aggregates from combustion of two fuels widely used in Asian rituals, J. Quant. Spectrosc. Ra., 122, 25-30, https://doi.org/10.1016/j.jqsrt.2012.12.011, 2013.

Chakrabarty, R. K., Moosmüller, H., Chen, L.-W. A., Lewis, K., Arnott, W. P., Mazzoleni, C., Dubey, M. K., Wold, C. E., Hao, W. M., and Kreidenweis, S. M.: Brown carbon in tar balls from smoldering biomass combustion, Atmos. Chem. Phys., 10, 63636370, https://doi.org/10.5194/acp-10-6363-2010, 2010.

Chakrabarty, R. K., Pervez, S., Chow, J. C., Watson, J. G., Dewangan, S., Robles, J., and Tian, G.: Funeral pyres in South Asia: Brown carbon aerosol emissions and climate impacts, Environ. Sci. Technol. Lett., 1, 44-48, https://doi.org/10.1021/ez4000669, 2014.

Chen, Y. and Bond, T. C.: Light absorption by organic carbon from wood combustion, Atmos. Chem. Phys., 10, 1773-1787, https://doi.org/10.5194/acp-10-1773-2010, 2010.

Chen, Y., Zhi, G., Feng, Y., Fu, J., Feng, J., Sheng, G., and Simoneit, B. R. T.: Measurements of emission factorsfor primary carbonaceous particles from residential raw- coal combustion in China, Geophys. Res. Lett., 33, L20815, https://doi.org/10.1029/2006gl026966, 2006.

Chen, Y., Tian, C., Feng, Y., Zhi, G., Li, J., and Zhang, G.: Measurements of emission factors of $\mathrm{PM}_{2.5}, \mathrm{OC}, \mathrm{EC}$, and $\mathrm{BC}$ for household stoves of coal combustion in China, Atmos. Environ., 109, 190-196, https://doi.org/10.1016/j.atmosenv.2015.03.023, 2015a.

Chen, Y., Zhi, G., Feng, Y., Tian, C., Bi, X., Li, J., and Zhang, G.: Increase in polycyclic aromatic hydrocarbon (PAH) emissions due to briquetting: A challenge to the coal briquetting policy, Environ. Pollut., 204, 58-63, https://doi.org/10.1016/j.envpol.2015.04.012, 2015b.

Chen, Y., Shen, G., Su, S., Du, W., Huangfu, Y., Liu, G., Wang, X., Xing, B., Smith, K. R., and Tao, S.: Efficiencies and pollutant emissions from forced-draft biomass-pellet semigasifier stoves: Comparison of International and Chinese water boiling test protocols, Energy Sustain. Dev., 32, 22-30, https://doi.org/10.1016/j.esd.2016.02.008, 2016.

Cheng, Y., Engling, G., He, K.-B., Duan, F.-K., Ma, Y.-L., Du, Z.Y., Liu, J.-M., Zheng, M., and Weber, R. J.: Biomass burning contribution to Beijing aerosol, Atmos. Chem. Phys., 13, 77657781, https://doi.org/10.5194/acp-13-7765-2013, 2013.

Cheng, Y., He, K., Du, Z., Engling, G., Liu, J., Ma, Y., Zheng, M., and Weber, R. J.: The characteristics of brown carbon aerosol during winter in Beijing, Atmos. Environ., 127, 355-364, https://doi.org/10.1016/j.atmosenv.2015.12.035, 2016.

Costabile, F., Gilardoni, S., Barnaba, F., Di Ianni, A., Di Liberto, L., Dionisi, D., Manigrasso, M., Paglione, M., Poluzzi, V., Rinaldi, M., Facchini, M. C., and Gobbi, G. P.: Characteristics of brown carbon in the urban Po Valley atmosphere, Atmos. Chem. Phys., 17, 313-326, https://doi.org/10.5194/acp-17-313-2017, 2017.

Duarte, R. M., Santos, E. B., Pio, C. A., and Duarte, A. C.: Comparison of structural features of water-soluble organic matter from atmospheric aerosols with those of aquatic humic substances, Atmos. Environ., 41, 8100-8113, https://doi.org/10.1016/j.atmosenv.2007.06.034, 2007.

Fan, X., Wei, S., Zhu, M., Song, J., and Peng, P.: Comprehensive characterization of humic-like substances in smoke PM2.5 emitted from the combustion of biomass materials and fossil fuels, Atmos. Chem. Phys., 16, 13321-13340, https://doi.org/10.5194/acp-16-13321-2016, 2016.

Feng, Y., Ramanathan, V., and Kotamarthi, V. R.: Brown carbon: a significant atmospheric absorber of solar radiation?, Atmos. Chem. Phys., 13, 8607-8621, https://doi.org/10.5194/acp13-8607-2013, 2013.

Fernandes, S. D., Trautmann, N. M., Streets, D. G., Roden, C, A., and Bond, T. C.: Global biofuel use, 1850-2000, Global Biogeochem. Cy., 21, GB2019, https://doi.org/10.1029/2006GB002836, 2007.

Ferrero, L., Gregorič, A., Močnik, G., Rigler, M., Cogliati, S., Barnaba, F., Di Liberto, L., Gobbi, G. P., Losi, N., and Bolzacchini, E.: The impact of cloudiness and cloud type on the atmospheric heating rate of black and brown carbon, Atmos. Chem. Phys. Discuss. [preprint], https://doi.org/10.5194/acp-2020-264, in review, 2020.

Fischer, K.: Measurements of absorption of visible radiation by aerosol particles, Contrib. Atmos. Phys., 43, 244-255, 1970.

Gustafsson, Ö., Kruså, M., Zencak, Z., Sheesley, R. J., Granat, L., Engström, E., Praveen, P. S., Rao, P. S. P., 
Leck, C., and Rodhe, H.: Brown clouds over south Asia: Biomass or fossil fuel combustion?, Science, 323, 495-497, https://doi.org/10.1126/science.1164857, 2009.

Han, H., Kim, G., Seo, H., Shin, K.-H., and Lee, D.-H.: Significant seasonal changes in optical properties of brown carbon in the midlatitude atmosphere, Atmos. Chem. Phys., 20, 2709-2718, https://doi.org/10.5194/acp-20-2709-2020, 2020.

He, Y., Huang, R., Wang, Q., Wang, Y., and Cao, J.: Temporal and spatial distribution of atmospheric PM1 concentration, compostion and source in China, China Powder Sci. Technol., 23, 1-10, https://doi.org/10.13732/j.issn.1008-5548.2017.03.001, 2017.

Healy, R. M., Wang, J. M., Jeong, C. H., Lee, A. K. Y., Willis, M. D., Jaroudi, E., Zimmerman, N., Hilker, N., Murphy, M., Eckhardt, E., Stohl, A., Abbatt, J. P. D., Wenger, J. C., and Evans, G. L.: Light-absorbing properties of ambient black carbon and brown carbon from fossil fuel and biomass burning sources, J. Geophys. Res.-Atmos., 120, 6619-6633, https://doi.org/10.1002/2015JD023382, 2015.

Hecobian, A., Zhang, X., Zheng, M., Frank, N., Edgerton, E. S., and Weber, R. J.: Water-Soluble Organic Aerosol material and the light-absorption characteristics of aqueous extracts measured over the Southeastern United States, Atmos. Chem. Phys., 10, 5965-5977, https://doi.org/10.5194/acp-10-5965-2010, 2010.

Heintzenberg, J.: Size-segregated measurement of particulate elemental carbon and aerosol light absorption at remote Arctic locations, Atmos. Environ., 16, 2461-2469, https://doi.org/10.1016/0004-6981(82)90136-6, 1982.

Hitzenberger, R. and Tohno, S.: Comparison of black carbon (BC) aerosols in two urban areas-concentrations and size distributions, Atmos. Environ., 35, 2153-2167, https://doi.org/10.1016/s13522310(00)00480-5, 2001.

Hitzenberger, R., Dusek, U., and Berner, A.: Black carbon measurements using an integrating sphere, J. Geophys. Res., 101, 1960119606, https://doi.org/10.1029/95jd02412, 1996.

Hitzenberger, R., Peezold, A., Bauer, H., Ctyroky, P., Pouresmaeil, P., Laskus, L., and Puxbaum, H.: Intercomparison of thermal and optical measurement methods for elemental carbon and black carbon at an urban location, Environ. Sci. Technol., 40, 63776383, https://doi.org/10.1021/es051228v, 2006.

Hoffer, A., Gelencsér, A., Guyon, P., Kiss, G., Schmid, O., Frank, G. P., Artaxo, P., and Andreae, M. O.: Optical properties of humiclike substances (HULIS) in biomass-burning aerosols, Atmos. Chem. Phys., 6, 3563-3570, https://doi.org/10.5194/acp-6-35632006, 2006.

Horvath, H.: Experimental calibration for aerosol light absorption measurements using the integrating plate methodsummary of the data, J. Aeros. Sci., 28, 1149-1161, https://doi.org/10.1016/S0021-8502(97)00007-4, 1997.

Huang, H., Ho, K. F., Lee, S. C., Tsang, P. K., Ho, S. S. H., Zou, C. W., Zou, S. C., Cao, J. J., and $\mathrm{Xu}, \mathrm{H}$. M.: Characteristics of carbonaceous aerosol in PM2.5: Pearl Delta River Region, China, Atmos. Res., 104-105, 227-236, https://doi.org/10.1016/j.atmosres.2011.10.016, 2012.

Huang, R. J., Yang, L., Cao, J., Chen, Y., Chen, Q., Li, Y., Duan, J., Zhu, C., Dai, W., Wang, K., Lin, C., Ni, H., Corbin, J. C., Wu, Y., Zhang, R. J., Tie, X., Hoffmann, T., O'Dowd, C., and Dusek, U.: Brown carbon aerosol in Urban Xi'an, Northwest China: The composition and light absorption properties, Sci. Total Environ., 52, 6825-6833, https://doi.org/10.1021/acs.est.8b02386, 2018.
Huo, Y., Li, M., Jiang, M., and Qi, W.: Light absorption properties of hulis in primary particulate matter produced by crop straw combustion under different moisture contents and stacking modes. Atmos. Environ., 191, 490-499, https://doi.org/10.1016/j.atmosenv.2018.08.038, 2018.

IPCC: Climate Change 2014: Synthesis Report. Contribution of Working Groups I, II and III to the Fifth Assessment Report of the Intergovernmental Panel on Climate Change, edited by: Pachauri, R. K. and Meyer, L. A., IPCC, Geneva, Switzerland, 151 pp., 2014.

Jacobson, M. Z.: Effects of biomass burning on climate, accounting for heat and moisture fluxes, black and brown carbon, and cloud absorption effects, J. Geophys. Res.-Atmos., 119, 8980 9002, https://doi.org/10.1002/2014JD021861, 2015.

Jiang, H., Li, J., Tang, J., Mo, Y., and Zhang, G.: Applications of high resolution mass spectrometry in studies of brown carbon, Chinese J. Anal. Chem., 46, 1528-1538, https://doi.org/10.11895/j.issn.0253-3820.171264, 2018.

Kirchstetter, T. and Novakov, T.: Evidence that the spectral dependence of light absorption by aerosols is affected by organic carbon, J. Geophys. Res., 109, D21208, https://doi.org/10.1029/2004jd004999, 2004.

Kirchstetter, T. W. and Thatcher, T. L.: Contribution of organic carbon to wood smoke particulate matter absorption of solar radiation, Atmos. Chem. Phys., 12, 6067-6072, https://doi.org/10.5194/acp-12-6067-2012, 2012.

Lack, D. A. and Langridge, J. M.: On the attribution of black and brown carbon light absorption using the Ångström exponent, Atmos. Chem. Phys., 13, 10535-10543, https://doi.org/10.5194/acp-13-10535-2013, 2013.

Lack, D. A., Langridge, J. M., Schwarz, J. P., Bahreini, R., Cappa, C. D., Middlebrook, A. M., and Schwarz, J. P.: Brown carbon and internal mixing in biomass burning particles, P. Natl. Acad. Sci. USA, 109, 14802-14807, https://doi.org/10.1073/pnas.1206575109, 2012.

Laskin, A., Laskin, J., and Nizkorodov, S. A.: Chemistry of atmospheric brown carbon, Chem. Rev., 115, 4335-4382, https://doi.org/10.1021/cr5006167, 2015.

Lei, Y., Shen, Z., Zhang, T., Zhang, Q., Wang, Q., Sun, J., Gong, X., Cao, J., Xu, H., and Liu, S.: Optical source profiles of brown carbon in size-resolved particulate matter from typical domestic biofuel burning over Guanzhong Plain, China, Sci. Total Environ., 622-623, 244-251, https://doi.org/10.1016/j.scitotenv.2017.11.353, 2018a.

Lei, Y., Shen, Z., Wang, Q., Zhang, T., Cao, J., Sun, J., Zhang, Q., Wang, L., Xu, H., Tian, J., and Wu, J.: Optical characteristics and source apportionment of brown carbon in winter PM2.5 over Yulin in Northern China, Atmos. Res., 213, 27-33, https://doi.org/10.1016/j.atmosres.2018.05.018, 2018 b.

Levinson, R., Akbari, H., and Berdahl, P.: Measuring solar reflectance - Part I: defining a metric that accurately predicts solar heat gain, Sol. Energy, 84, 1745-1759, https://doi.org/10.1016/j.solener.2010.04.018, 2010.

Li, S., Zhu, M., Yang, W., Tang, M., Huang, X., Yu, Y., Fang, H., Yu, X., Yu, Q., Fu, X., Song, W., Zhang, Y., Bi, X., and Wang, X.: Filter-based measurement of light absorption by brown carbon in PM2.5 in a megacity in South China, Sci. Total Environ., 633, 1360-1369, https://doi.org/10.1016/j.scitotenv.2018.03.235, 2018. 
Lin, P., Bluvshtein, N., Rudich, Y., Nizkorodov. S., Laskin, J., and Lasin, A.: Molecular chemistry of atmospheric brown carbon inferred from a nationwide biomass burning event, Environ. Sci. Technol., 51, 11561-11570, https://doi.org/10.1021/acs.est.7b02276, 2017.

Lu, B., Kong, S., Han, B., Wang, X., and Bai, Z.: Inventory of atmospheric pollutants discharged from biomass burning in China continent in 2007, China Environ. Sci., 31, 186-194, https://doi.org/10.3724/SP.J.1077.2011.00311, 2011.

Lukács, H., Gelencsér, A., Hammer, S., Puxbaum, H., Pio, C., Legrand, M., Kasper-Giebl, A., Handler, M., Limbeck, A., Simpson, D., and Preunkert, S.: Seasonal trends and possible sources of brown carbon based on 2-year aerosol measurements at six sites in Europe, J. Geophys. Res., 112, D23S18, https://doi.org/10.1029/2006JD008151, 2007.

Martinsson, J., Eriksson, A. C., Nielsen, I. E., Malmborg, V. B., Ahlberg, E., Andersen, C., Lindgren, R., Nystrom, R., Nordin, E. Z., Brune, W. H., Svenningsson, B., Swietlicki, E., Boman, C., and Pagels, J. H.: Impacts of Combustion Conditions and Photochemical Processing on the Light Absorption of Biomass Combustion Aerosol, Environ. Sci. Technol., 49, 14663-14671, https://doi.org/10.1021/acs.est.5b03205, 2015.

Medalia, A. I., Rivin, D., and Sanders, D. R.: A comparison of carbon black with soot, Sci. Total Environ., 31, 1-22, https://doi.org/10.1016/0048-9697(83)90053-0, 1983.

Mo, Y., Li, J., Liu, J., Zhong, G., Cheng, Z., Tian, C., Chen, Y., and Zhang, G.: The influence of solvent and $\mathrm{PH}$ on determination of the light absorption properties of water-soluble brown carbon, Atmos. Environ., 161, 90-98, https://doi.org/10.1016/j.atmosenv.2017.04.037, 2017.

National Bureau of Statistics of China (NBSC): China Energy Statistical Yearbook 2014, China Statistics Press, Beijing, China, 2014.

Park, R. J., Kim, M. J., Jeong, J. I., Youn, D., and Kim, S.: A contribution of brown carbon aerosol to the aerosol light absorption and its radiative forcing in East Asia, Atmos. Environ., 44, 14141421, https://doi.org/10.1016/j.atmosenv.2010.01.042, 2010.

Phillips, S. M., Bellcross, A. D., and Smith, G. D.: Light absorption by brown carbon in the Southeastern United States is PH-dependent, Environ. Sci. Technol., 51, 6782-6790, https://doi.org/10.1021/acs.est.7b01116, 2017.

Pokhrel, R. P., Beamesderfer, E. R., Wagner, N. L., Langridge, J. M., Lack, D. A., Jayarathne, T., Stone, E. A., Stockwell, C. E., Yokelson, R. J., and Murphy, S. M.: Relative importance of black carbon, brown carbon, and absorption enhancement from clear coatings in biomass burning emissions, Atmos. Chem. Phys., 17, 5063-5078, https://doi.org/10.5194/acp-17-5063-2017, 2017.

Ran, Y., Wang, C., Liu, Q., Chen, Z., Ding, Z., and Zhang, J.: Utilization status, problems and countermeasures of rural household biomass stoves, Agric. Eng. Technol., 2, 28-31, 2014.

Reid, J. S., Koppmann, R., Eck, T. F., and Eleuterio, D. P.: A review of biomass burning emissions part II: intensive physical properties of biomass burning particles, Atmos. Chem. Phys., 5, 799825, https://doi.org/10.5194/acp-5-799-2005, 2005.

Reisinger, P., Wonaschütz, A., Hitzenberger, R., Petzold, A., Bauer, H., and Jankowski, N.: Intercomparison of measurement techniques for black or elemental carbon under urban background conditions in wintertime: Influence of biomass combustion, Environ. Sci. Technol., 42, 884-889, https://doi.org/10.1021/es0715041, 2008.

Rosen, H., Hansen, A. D. A., Gundel, L., and Novakov, T.: Identification of optically absorbing component in urban aerosols, Appl. Optics, 17, 3859-3861, https://doi.org/10.1364/AO.17.003859, 1978.

Saleh, R., Robinson, E. S., Tkacik, D. S., Ahern, A. T., Liu, S., Aiken, A. C., Sullivan, R. C., Presto, A. A., Dubey, M. K., Yokelson, R. J., Donahue, N. M., and Robinson, A. L.: Brownness of organics in aerosols from biomass burning linked to their black carbon content, Nat. Geosci., 7, 647-650, https://doi.org/10.1038/ngeo2220, 2014.

Schmidl, C., Bauer, H., Hitzenberger, R., Weissenboeck, G., Marr, I., and Puxbaum, H.: Chemical characterisation of fine particle emissions from burning leaves, Atmos. Environ., 42, 9070-9079, https://doi.org/10.1016/j.atmosenv.2008.09.010, 2008.

Shen, G., Tao, S., Wei, S., Chen, Y., Zhang, Y., Shen, H., Huang, Y., Zhu, D., Yuan, C., Wang, H., Wang, Y., Pei, L., Liao, Y., Duan, Y., Wang, B., Wang, R., Lv, Y., Li, W., Wang, X., and Zheng, X.: Field measurement of emission factors of PM, EC, OC, parent, nitro-, and oxy- polycyclic aromatic hydrocarbons for residential briquette, coal cake, and wood in rural Shanxi, China, Environ. Sci. Technol., 47, 2998-3005, https://doi.org/10.1021/es304599g, 2013.

Shen, G., Xue, M., Chen, Y., Yang, C., Li, W., Shen, H., Huang, Y., Zhang, Y., Chen, H., Zhu, Y., Wu, H., Ding, A., and Tao, S.: Comparison of carbonaceous particulate matter emission factors among different solid fuels burned in residential stoves, Atmo. Environ., 89, 337-345, https://doi.org/10.1016/j.atmosenv.2014.01.033, 2014.

Srinivas, B. and Sarin, M. M.: Light absorbing organic aerosols (brown carbon) over the tropical Indian Ocean: Impact of biomass burning emissions, Environ. Res. Lett., 8, 1-7, https://doi.org/10.1088/1748-9326/8/4/044042, 2013.

Srinivas, B. and Sarin, M. M.: Brown carbon in atmospheric outflow from the Indo-Gangetic Plain: Mass absorption efficiency and temporal variability. Atmos. Environ., 89, 835-843, https://doi.org/10.1016/j.atmosenv.2014.03.030, 2014.

Srinivas, B., Rastogi, N., Sarin, M. M., Singh, A., and Singh, D.: Mass absorption efficiency of light absorbing organic aerosols from source region of paddy-residue burning emissions in the Indo-Gangetic Plain, Atmos. Environ., 125, 360-370, https://doi.org/10.1016/j.atmosenv.2015.07.017, 2016.

Sun, J., Zhi, G., Hitzenberger, R., Chen, Y., Tian, C., Zhang, Y., Feng, Y., Cheng, M., Zhang, Y., Cai, J., Chen, F., Qiu, Y., Jiang, Z., Li, J., Zhang, G., and Mo, Y.: Emission factors and light absorption properties of brown carbon from household coal combustion in China, Atmos. Chem. Phys., 17, 4769-4780, https://doi.org/10.5194/acp-17-4769-2017, 2017.

Sun, J., Zhi, G., Jin, W., Chen, Y., Shen, G., Tian, C., Zhang, Y., Zong, Z., Cheng, M., Zhang, X., Zhang, Y., Liu, C., Lu, J., Wang, H., Xiang, J., Tong, L., and Zhang, X.: Emission factors of organic carbon and elemental carbon for residential coal and biomass fuels in China - A new database for 39 fuel-stove combinations, Atmos. Environ., 190, 241-248, https://doi.org/10.1016/j.atmosenv.2018.07.032, 2018.

Sun, $\mathrm{X}$. and $\mathrm{Xu}, \mathrm{M}$.: Application of biomass briquetting technology, Jiangsu Agric. Mechan., 3, 32-33, 2012 (in Chinese). 
The World Bank: China - Accelerating household access to clean cooking and heating, available at: http: //documents1.worldbank.org/curated/en/401361468022441202/ pdf/814950WP0P12980Box0379837B00PUBLIC0.pdf (last access: 1 July 2020), 2013.

Tian, H., Zhao, D., and Wang, Y.: Emission inventories of atmospheric pollutants discharged from biomass burning in China, Acta Sci. Circum., 31, 349-357, https://doi.org/10.13671/j.hjkxxb.2011.02.018, 2011 (in Chinese).

Voisin, D., Jaffrezo, J. L., Houdier, S., Barret, M., Cozic, J., King, M. D., France, J. L., Reay, H. J., Grannas, A., Kos, G., Ariya, P. A., Beine, H. J., and Domine, F.: Carbonaceous species and humic like substances (HULIS) in Arctic snowpack during OASIS field campaign in Barrow, J. Geophys. Res., 117, D00R19, https://doi.org/10.1029/2011jd016612, 2012.

Washenfelder, R. A., Attwood, A. R., Brock, C. A., Guo, H., Xu, L., Weber, R. J., Ng, N. L., Allen, H. M., Ayres, B. R., Baumann, K., Cohen, R. C., Draper, D. C., Duffey, K. C., Edgerton, E., Fry, J. L., Hu, W. W., Jimenez, J. L., Palm, B. B., Romer, P., Stone, E. A., Wooldridge, P. J., and Brown, S. S.: Biomass burning dominates brown carbon absorption in the rural southeastern United States, Geophys. Res. Lett., 42, 653-664, https://doi.org/10.1002/2014gl062444, 2015.

Wei, S., Song, J., Peng, P., and Yu, C.: Py-GC/MS study on the characteristics of soot and charcoal derived from biomass materials and coal, Geochimica. 46, 240-251, https://doi.org/10.19700/j.0379-1726.2017.03.004, 2017.

Wiedinmyer, C., Akagi, S. K., Yokelson, R. J., Emmons, L. K., AlSaadi, J. A., Orlando, J. J., and Soja, A. J.: The Fire INventory from NCAR (FINN): a high resolution global model to estimate the emissions from open burning, Geosci. Model Dev., 4, 625641, https://doi.org/10.5194/gmd-4-625-2011, 2011.

Wonaschütz, A., Hitzenberger, R., Bauer, H., Pouresmaeil, P., Klatzer, B., Caseiro, A., and Puxbaum, H.: Application of the integrating sphere method to separate the contributions of brown and black carbon in atmospheric aerosols, Environ. Sci. Technol., 43, 1141-1146, https://doi.org/10.1021/es8008503, 2009.

Wu, G., Ram, K., Fu, P., Wang, W., Zhang, Y., Liu, X., Stone, E., Pradhan, B. B., Dangol, P. M., Panday, A., Xin, W., Bai, Z., Kang, S., Zhang, Q., and Cong, Z.: Water-soluble brown carbon in atmospheric aerosols from Godavari (Nepal), a regional representative of south Asia, Environ. Sci. Technol., 53, 3471-3479, https://doi.org/10.1021/acs.est.9b00596, 2019.

Xie, M., Shen, G., Holder, A. L., Hays, M., and Jetter, J.: Light absorption of organic carbon emitted from burning wood, charcoal, and kerosene in household cookstoves, Environ. Polluti., 240, 60-67, https://doi.org/10.1016/j.envpol.2018.04.085, 2018.

Yan, C., Zheng, M., Sullivan, A. P., Bosch, C., Desyaterik, Y., Andersson, A., Li, X., Guo, X., Zhou, T., Gustafsson, Ö., and Collett, J. L.: Chemical characteristics and lightabsorbing property of water-soluble organic carbon in Beijing: Biomass burning contributions, Atmos. Environ., 121, 4-12, https://doi.org/10.1016/j.atmosenv.2015.05.005, 2015.

Yan, F., Kang, S., Sillanpää, M., Hu, Z., Gao, S., Chen, P., Gautam, S., Reinikainen, S., and Li, C.: A new method for extraction of methanol-soluble brown carbon: Implications for investigation of its light absorption ability, Environ. Pollut., 262, 114300, https://doi.org/10.1016/j.envpol.2020.114300, 2020.
Yan, J., Wang. X., Gong, P., Wang, C., and Cong, Z.: Review of brown carbon aerosols: Recent progress and perspectives, Sci. Total Environ., 634, 1475-1485, https://doi.org/10.1016/j.scitotenv.2018.04.083, 2018.

Yang, M., Howell, S. G., Zhuang, J., and Huebert, B. J.: Attribution of aerosol light absorption to black carbon, brown carbon, and dust in China - interpretations of atmospheric measurements during EAST-AIRE, Atmos. Chem. Phys., 9, 2035-2050, https://doi.org/10.5194/acp-9-2035-2009, 2009.

Yao, H., Song, Y., Liu, M., Archer-Nicholls, S., Lowe, D., McFiggans, G., Xu, T., Du, P., Li, J., Wu, Y., Hu, M., Zhao, C., and Zhu, T.: Direct radiative effect of carbonaceous aerosols from crop residue burning during the summer harvest season in East China, Atmos. Chem. Phys., 17, 5205-5219, https://doi.org/10.5194/acp-17-5205-2017, 2017.

Yao, L.: Study on the chemical composition, origin and secondary generation of atmospheric $\mathrm{PM}(2.5)$ in typical areas of Shandong Province, PhD thesis, Shandong University, 2016.

Yuan, J.-F., Huang, X.-F., Cao, L.-M., Cui, J., Zhu, Q., Huang, C.N., Lan, Z.-J., and He, L.-Y.: Light absorption of brown carbon aerosol in the PRD region of China, Atmos. Chem. Phys., 16, 1433-1443, https://doi.org/10.5194/acp-16-1433-2016, 2016.

Zhang, X., Kim, H., Parworth, C., Young, D., Zhang, Q., Metcalf, A. R., and Cappa, C.: Optical Properties of Wintertime Aerosols from Residential Wood Burning in Fresno, CA: Results from DISCOVER-AQ 2013, Environ. Sci. Technol., 50, 1681-1690, https://doi.org/10.1021/acs.est.5b04134, 2016.

Zhang, Y., Shen, Z., Zhang, B., Sun, J., Zhang, L., Zhang, T., Xu, H., Bei, N., Tian, J., Wang, Q., and Cao, J.: Emission reduction effect on $\mathrm{PM}_{2.5}, \mathrm{SO}_{2}$ and $\mathrm{NO}_{x}$ by using red mud as additive in clean coal briquetting, Atmos. Environ., 223, 117203, https://doi.org/10.1016/j.atmosenv.2019.117203, 2020.

Zhao, C. and Luo, K.: Household consumption of coal and related sulfur, arsenic, fluorine and mercury emissions in China, Energ. Policy, 112, 221-232, https://doi.org/10.1016/j.enpol.2017.10.021, 2018.

Zhi, G., Chen, Y., Feng, Y., Xiong, S., Li, J., Zhang, G., Sheng, $\mathrm{G}$., and $\mathrm{Fu}$, J.: Emission characteristics of carbonaceous particles from various residential coal-stoves in China, Environ. Sci. Technol., 42, 3310-3315, https://doi.org/10.1021/es702247q, 2008.

Zhi, G., Peng, C., Chen, Y., Liu, D., Sheng, G., and Fu, J.: Deployment of coal briquettes and improved stoves: possibly an option for both environment and climate, Environ. Sci. Technol., 43, 5586-5591, https://doi.org/10.1021/es802955d, 2009.

Zhi, G., Yang, J., Zhang, T., Guan, J., Du, J., Xue, Z., and Meng, F.: Rural household coal use survey, emission estimation and policy implications, Res. Environ. Sci., 28, 1179-1185, https://doi.org/10.13198/j.issn.1001-6929.2015.08.01, 2015a (in Chinese).

Zhi, G., Cai, J, Yang, J., Chen, Y., Zhang, W., Cheng, M., and Sun, J.: Origin, properties, measurement and emission estimation of brown carbon aerosols, Res. Environ. Sci., 28, 1797-1814, https://doi.org/10.13198/j.issn.1001-6929.2015.12.01, 2015b (in Chinese).

Zong, Z., Wang, X., Tian, C., Chen, Y., Fang, Y., Zhang, F., Li, C., Sun, J., Li, J., and Zhang, G.: First assessment of NOx sources at a regional background site in North China using isotopic analysis linked with modeling, Environ. Sci. Technol., 51, 5923-5931, https://doi.org/10.1021/acs.est.6b06316, 2017. 